\title{
THE BEHAVIOURAL ATTRIBUTES ABOUT A COMPRESSION IGNITION ENGINE POWERED WITH DIESEL AND Artocarpus heterophyllus METHYL ESTER BLENDS
}

\author{
T. Nambaya Charyulu ${ }^{1, *}$, P. Naveenchandran ${ }^{2}$, E. Raja ${ }^{3}$ and R. N. Babu ${ }^{4}$ \\ ${ }^{1}$ Research Scholar, BIHER (Bharath University), Chennai-6000073, India \\ ${ }^{1}$ Mechanical Engineering Department, SVIST, Tiruvuru-521235, Andhra Pradesh, India \\ ${ }^{2,3}$ Automobile Engineering Department, Bharath Institute of Higher Education \& Research \\ (Bharath University), Chennai-6000073, India \\ ${ }^{4}$ Mechanical Engineering Department, SVIST, Tiruvuru-521235, Andhra Pradesh, India \\ *E-mail: tnchoney@gmail.com
}

\begin{abstract}
This paper presents the impact of biodiesel extracted from Artocarpus heterophyllus seeds commonly known as jackfruit seeds. The crude jackfruit oil was transformed into Artocarpus heterophyllus Methyl Ester by the transesterification process. The thermophysical properties are found to be approximately like that of fossil diesel. Various biodiesel and mineral diesel blends are prepared to range from $10 \%-30 \%$ and the blends are designated as AHME10D90, AHME20D80, and AHME30D70. A single-cylinder diesel engine was tested and the result revealed that AHME30D70 exhibited better performance, and emission results than the other two, the brake specific fuel consumption, brake thermal efficiency, and exhaust gas temperature were improved by $3.46 \%, 6.39 \%$, and $13.20 \%$ respectively. Carbon monoxide emission was decreased by $57.74 \%$ and oxides of nitrogen emission were increased by $13.20 \%$ as compared to pure diesel.
\end{abstract}

Keywords: Artocarpus heterophyllus Seeds, Jackfruit Seeds, Artocarpus heterophyllus Methyl Ester, Transesterification, Thermophysical Properties

(C) RASĀYAN. All rights reserved

\section{INTRODUCTION}

Renewable energy is a hopeful source of energy for future success to keep the environment in a safe zone. Bioenergy was anticipated to diminish the dependency on conventional fossil fuels with its connected governmental and lucrative infirmity, minimize the greenhouse emissions and other related issues to reinvigorate the financial wealth to increase the demand and prices of the agricultural outcomes. It was expected that shortly half of the universal energy demand will be fulfilled by renewable energy by $2040 .{ }^{1}$ Biomass at present is the most favorable renewable resource of energy and it would be continued in the upcoming days. It was judged that the current available crude oil reserves will vanish within a short period of nearly 50 years at the present rate of utilization. ${ }^{2}$ In 1925 Henry Ford said that we can get fuel from every fruit, but the problem is how this fuel can be produced commercially at a cheaper rate than presently available fossil fuels. During this journey to find out a suitable feedstock that might be edible or non-edible for producing biodiesel, several investigations are discussed as under,

N. Charyulu T and P. Naveenchandran have reviewed the momentousness of biodiesel extricated from various sources of vegetable feedstocks as a replaceable fuel to petroleum diesel. ${ }^{3}$ Hwai Chyuan Ong et al. have produced biodiesel from Crude Cerbera Manghas bio-fuel by two-step acid-alkaline transesterification using $\mathrm{H}_{2} \mathrm{SO} 4$ as the acid catalyst and $\mathrm{KOH}$ as the alkaline catalyst, finally, they have proposed that non-edible oil derived out of Cerbera Manghas could be considered as an ensuing biodiesel feedstock. ${ }^{4}$ A.E. Atabani et al. have investigated the potentiality of Calophyllum inophyllum seed as a feedstock to develop biodiesel extraction and reported that Calophyllum inophyllum showed the signs of good enough raw material for producing biodiesel in coming days. ${ }^{5} \mathrm{~N}$. Charyulu $\mathrm{T}$ and $\mathrm{P}$. Naveenchandran did experimentation on a single-cylinder four-stroke diesel engine to find its

Rasayan J. Chem., 13(2), 876-886(2020)

http://dx.doi.org/10.31788/RJC.2020.1325560

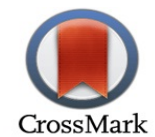


RASĀYAN J. Chem.

Vol. 13 | No. 2 |876 - 886| April - June | 2020

characteristic features under the influence of the blends of diesel and microalgae biodiesel, and they have got better performance and emission results with $30 \%$ of blend. ${ }^{6}$ R. Satish Kumar et al. have derived biodiesel called Manilkara Zapota Methyl Ester extracted from Manilkara Zapota commonly known as Sapota Seeds by adopting the Taguchi technique, and the thermophysical properties were getting similar to that of biodiesel recommendations, and it was reported that it could be reflected as a potential replacement to fossil diesel. ${ }^{7}$ S. Sendilvelan and K. Bhaskar have examined the impact of $15 \%$ of Dried De-Oiled Coconut Cake blended with Pure Diesel and 15\% of Jatropha Methyl Ester blended with Pure Diesel on the emission and performance characteristics of a diesel engine and the final experimental results revealed that the emission parameters except for oxides of nitrogen were improved with an improvement in brake thermal efficiency as compared to mineral diesel. ${ }^{8} \mathrm{~N}$. Charyulu $\mathrm{T}$ and $\mathrm{P}$. Naveenchandran have probed the effect of fuel injection pressure on the behavior of a naturally aspirated, direct-injection single-cylinder compression ignition engine fueled with $30 \%$ microalgae methyl ester and $70 \%$ pure diesel. ${ }^{9}$ V.K. Shahir et al. have carried out an extensive literature review on several biodiesels and stated that $20 \%$ mixing of bio-diesel with fossil fuel could be a better choice for long run diesel engines applications without any engine modifications. ${ }^{10} \mathrm{M}$. Mofijur et al. have reviewed the influence of biofuels on internal combustion engine emissions reduction and have promulgated that, biofuels are capable to reduce Green House Gas emissions more than $80 \%$. Some of the emergent nations such as the United States are aimed to make use of $25 \%$ of ethanol by 2020, Brazil put a target to carry through B20 within 2020 and India was executed to utilize B10 over nationwide by $2017 .{ }^{11} \mathrm{~N}$. Charyulu T and P. Naveenchandran had conducted a test with Manilkara zapota seed biodiesel to perceive the mannerism of a compression ignition engine and revealed its suitability as a substitute for conventional diesel. ${ }^{12} \mathrm{M}$. Saravanakumar et al. have carried out an emission test on diesel engine with pure diesel, pure used cooking oil methyl ester and used cooking oil methyl ester and pure diesel blend, and the test reported that the emissions of carbon monoxide, particulate matter, unburned hydrocarbon, and smoke intensity were observed low with pure used cooking oil methyl ester bur oxides of nitrogen was found more compared to pure diesel and used cooking oil methyl ester and pure diesel blend. ${ }^{13}$ A.K. Azad et al. have reviewed that, Moringa Oleifera seed oil has the potential to produce biodiesel and it is one of the promising seed that yields $38-40 \%$ of colorless and odorless vegetable oil, and as biodiesel, it gives lower engine performance, lower emissions of $\mathrm{CO}, \mathrm{CO}_{2}, \mathrm{PM}, \mathrm{HC}$, and little higher NOx emissions than fossil diesel. ${ }^{14}$ R.M. Alagu and E.G. Sundaram prepared a Pyrolytic oil from neem seed and examined the influence of pyrolytic oil and pure diesel blends on the performance, emission and combustion characteristics of a compression ignition engine. ${ }^{15} \mathrm{~J}$. Kakati et al. have produced Amari Seed oil from Amari tree seeds and stated that Amari is a forest-based tree and the seed contains the percentage of oil content was found to be $42.85 \%$, Linoleic acid was $32.84 \%$, and oleic acid was $23.01 \%$, and also reported that the free fatty acid content was $16 \%$ which causes to use two stages transesterification to produce biodiesel. ${ }^{16}$ L.Tarabet et al. have tested the emission characteristics of a modified diesel engine using Eucalyptus derived biodiesel and natural gas with dual fuel mode of operation which resulted in reduced oxides of nitrogen (NOx) emissions than the mineral diesel. ${ }^{17}$ Md. F. AI. Dawody and SK. Bhatti had reported the emission limitations of a CI engine powered by Soybean Biodiesel-Diesel blends as soybean methyl ester emits lower unburned hydrocarbon and higher NOx as compared to that of pure diesel fuel. ${ }^{18}$ Md. Narun Nabi et al. tested a new renewable Licella biofuel in a multi-cylinder turbocharged CRDI (common rail direct injection) diesel engine and found no significant differences in performance parameters and also noticed that NO emission was found to be higher. ${ }^{19}$ Isaac Joshua Ramesh Lalvani et al. have explored the outcome of Adelfa biofuel on single-cylinder diesel engine without and with a modified piston to increase the turbulence for better amalgamation of fuel and air, finally stated that the engine with modified piston had shown improved performance and emission parameters except for nitrogen oxide. ${ }^{20}$

$\mathrm{N}$. Nallusamy et al. have analyzed the influence of pine oil and mineral diesel blends on the characteristic features like performance, combustion and emissions of a compression ignition engine, the result confirmed that a slight increase was found in brake thermal efficiency and a decrease was found in brake specific fuel consumption and also reduction was found in emissions of carbon monoxide, hydrocarbon but nitrogen oxide was increased. ${ }^{21}$ S.M. Ameer Uddin et al. effectuated an experimental evaluation on 
RASĀYAN J. Chem.

Vol. 13 | No. 2 |876 - 886| April - June | 2020

diesel engine accompanied by Mustard-Kerosene blends, and they have stated that it could be considered as a suitable replacement for pure diesel. ${ }^{22}$ Omar I. Awad et al. have experimentally found the effect of fusel oil on the emission and performance features of a single-cylinder compression ignition engine and revealed that the engine power and torque slightly dropped for $20 \%$ of the blend as compared with diesel, further a reduction in oxides of nitrogen was recorded. ${ }^{23} \mathrm{~K}$. Khiari et al. verified the various features of biodiesel extracted from Pistacia Lentiscus seeds in a normal compression ignition engine and the results reported that the brake thermal efficiency and the emission levels were considerably improved, on the other hand, BSFC and NOx emission was increased. ${ }^{24}$ Harveer Singh Pali and Naveen Kumar have tested a diesel engine fueled with Sal Methyl Ester obtained from Shorea Robusta seed oil, during the test important characteristics were observed. The derived data were shown that Sal Methyl Ester and Diesel blend is a probable environment-friendly fuel for compression ignition engines. ${ }^{25}$ Ashok Kumar Yadav et $a l$. have prepared Oleander seed biodiesel using ultrasonic transesterification process, and they have made a trail on one cylinder diesel engine powered by Oleander seed biodiesel, and they have reported that $20 \%$ Oleander biodiesel could be used in an unmodified diesel engine effectively. ${ }^{26}$ Praveen A. Harari had experimented to analyze the features of a single-cylinder diesel engine running on Water Melon seed biodiesel, and the conclusion revealed that among all the blends B20 showed the closer performance with the neat diesel. ${ }^{27}$ B. Dhinesh and M. Annamalai have performed a test on compression ignition engine to find its properties when running on cerium oxide nanoparticles mixed with an emulsion of Nerium oleander biofuel and the experimental data was depicted that considerable reduction was found in the emission parameters such as carbon monoxide, smoke opacity, unburned hydrocarbon, and nitrogen oxides when compared with fossil fuel. ${ }^{28} \mathrm{R}$. Sundara Raman et al. had experimented on the diesel engine to evaluate the emission limitations using esterified rice bran oil and non-esterified rice bran oil and detected that the emissions of NOx and unburned hydrocarbon were reduced and the emissions of carbon monoxide, particulate matter, and smoke opacity were found to be increased. ${ }^{29} \mathrm{M}$. Rengasamy et al. have drawn-out oil from the seeds of Artocarpus heterophyllus commonly known as Jackfruit and studied its utilization to produce Biodiesel. This study reported that $19.8 \%$ of optimum yield was obtained using the microwave oven extraction process when methanol as solvent and they have stated that the biodiesel yield was about $92 \%$ by transesterification at a temperature of $65^{\circ} \mathrm{c}$ with sodium hydroxide as a catalyst. ${ }^{30}$ Nagarajan Jeyakumar et al. have optimized the reaction parameters like methanol-oil ratio, catalyst, reaction time and reaction temperature to increase the yield of jackfruit methyl ester from jackfruit seed oil by adopting response surface strategy and finally they have claimed that $92.5 \%$ of yield was obtained at 1:8 molar ratio, the reaction time of $90 \mathrm{~min}$, reaction temperature at $60^{\circ} \mathrm{c}$, and $0.6 \mathrm{wt} . \%$ of sodium hydroxide as a catalyst. ${ }^{31}$

After going through several experimental studies on various biodiesels, Artocarpus heterophyllus was selected as feedstock to produce biodiesel as it is being newly introduced. Artocarpus heterophyllus or jackfruit is a tropical evergreen tree and heightens up to $20 \mathrm{~m}$. Its fruit is large and having sharp projecting points. The jackfruit is cultivated for a wide range of applications such as ashes of the leaves are used for treating Ulcers, diarrhea, stomach-ache, etc., and not only the above but also it has got many medicinal benefits. This fruit is edible either by devouring raw pulp directly after ripping or by cooking the seeds after peeling. The powder of this seed can be used in the biscuit making process in the bakery industry. Jackfruit can be used as a pesticide to overcome the issue of soil erosion due to its extensive root system. The wood of this tree can reduce the risk of termite attack due to its resistant property against termite, fungal and bacteria, it can also be used as cooking wood. In many parts of India, after taking the pulp, seeds are thrown and can be used as a feedstock to produce biodiesel. ${ }^{30,31}$

The current study was conducted on a single-cylinder water-cooled direct injection Kirloskar made compression ignition engine powered by Artocarpus heterophyllus methyl ester and fossil diesel mixtures. The blends were prepared in ratios $10 \%, 20 \%$ and $30 \%$ of AHME mixed with pure diesel. The biodiesel was prepared from Jackfruit crude oil using alkaline-based transesterification activity. The physicochemical properties of Artocarpus heterophyllus methyl ester were found and checked with mineral diesel. The diesel engine was tested at fixed rated speed $(1500 \mathrm{rpm})$ with various load conditions from $0-100 \%$ running with pure diesel, and AHME10D90, AHME20D80, and AHME30D70. The engine performance parameters (BSFC, BTE), combustion parameters (cylinder peak pressure, maximum heat 
RASĀYAN J. Chem.

Vol. 13 | No. 2 |876 - 886| April - June | 2020

release rate and Ignition Delay) and emission parameters (EGT, $\mathrm{CO}_{2}, \mathrm{CO}, \mathrm{HC}, \mathrm{NO}_{\mathrm{X}}$ and smoke opacity) were recorded and analyzed.

\section{EXPERIMENTAL}

\section{Biodiesel Preparation}

A required quantity of crude jackfruit oil was procured from local biodiesel manufactures of Chidambaram in Tamilnadu, and it was gone through transesterification to turn raw oil into bio-diesel. Transesterification is one of the most suitable and reliable methods to transform the raw vegetable oil into usable fuel in the compression ignition engine, it involves chemical reaction to convert long branching triglyceride molecules of oil derived from vegetarian and fats of animal or fish into small straight-chain molecules as the equivalent size of fossil diesel fuel. This process took place due to the reaction between vegetable oil and methyl alcohol or ethyl alcohol in the company of an alkaline catalyst such as potassium hydroxide or sodium hydroxide. One-liter raw jackfruit seed oil was taken in a round bottom flask, and 18 grams of potassium hydroxide and $250 \mathrm{ml}$ of methyl alcohol were taken in a glass container and both are agitated till $\mathrm{KOH}$ gets diffused completely in a methyl alcohol solution. The raw jackfruit seed oil which was already taken was heated to $60^{\circ} \mathrm{c}$ using magnetic stirrer cum heater, after reaching $60^{\circ} \mathrm{c}$, the methanol-KOH solution was poured into raw oil. This raw oil-methanol-KOH solution is then heated continuously at $60^{\circ} \mathrm{c}$ with stirring speed at $720 \mathrm{rpm}$ for 3 to 4 hours, then after this solution was shifted to separating funnel and left it for settling overnight. After settlement, glycerol was separated and biodiesel was subjected to repeated water wash and heating above $100^{\circ} \mathrm{c}$ to evaporate the water particles and methanol associated with biodiesel, now the biodiesel is ready to use in compression ignition engines. Thermo-physical properties of Artocarpus heterophyllus Methyl Ester were found at ETA lab, Chennai and reported in Table- 1 .

Table-1: Thermophysical Properties of Artocarpus heterophyllus Methyl Ester

\begin{tabular}{c|l|c|c|c|c}
\hline S.No. & \multicolumn{1}{|c|}{ Fuel Property } & ASTM & Diesel Fuel & Biodiesel & AHME \\
\hline 1 & Density $\left(\mathrm{Kg} / \mathrm{m}^{3}\right)$ & $\mathrm{D}-4052$ & $820-860$ & $860-900$ & 877 \\
\hline 2 & Kinematic Viscosity $@ 40^{\circ} \mathrm{C}\left(\mathrm{mm}^{2} / \mathrm{S}\right)$ & $\mathrm{D}-445$ & $2.6-5.7$ & $1.9-6.0$ & 6.78 \\
\hline 3 & Flash Point $\left({ }^{0} \mathrm{C}\right)$ & $\mathrm{D}-92$ & $60-80$ & Min.130 & 186 \\
\hline 4 & Cetane Number & $\mathrm{D}-613$ & $40-55$ & Min.47 & 44 \\
\hline 5 & Calorific Value $(\mathrm{Kj} / \mathrm{Kg})$ & $\mathrm{D}-240$ & $42000-46000$ & --- & 38041 \\
\hline
\end{tabular}

\section{Experimental Setup}

This work has been executed on a Kirloskar TV1 single-cylinder, naturally aspirated, water-cooled, compression ignition engine of $5.12 \mathrm{KW}$ of brake power at a rated speed of $1500 \mathrm{rpm}$. The main perspective of this investigation towards the evaluation of the features of performance, emission and combustion for the above-said engine when it was powered with AHME and diesel blends and the blends are designated as, AHME10D90, AHME20D80, and AHME30D70. The photographic view of the engine setup was shown in Fig.-1 and the test rig specifications are depicted in Table-2.

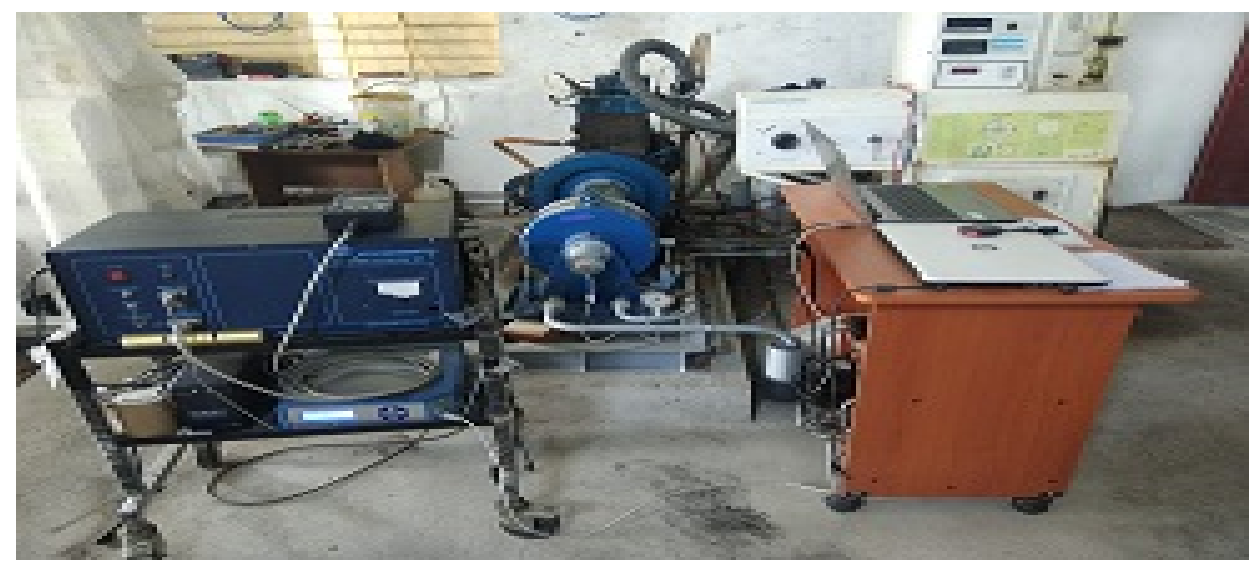

Fig.-1: Photographic View of Engine Setup 
RASĀYAN J. Chem.

Vol. 13 | No. 2 |876 - 886| April - June | 2020

Table-2: Specifications of the Test Rig ${ }^{6,9,12}$

\begin{tabular}{c|c}
\hline Make & Kirloskar \\
\hline Model & TV 1 \\
\hline Type & 1- cylinder, 4-stroke, vertical diesel engine \\
\hline Rated Power & $1500 \mathrm{KWm}$ \\
\hline Rated Speed & $87.5 \mathrm{~mm}$ \\
\hline Cylinder bore & $110 \mathrm{~mm}$ \\
\hline Stroke Length & $17.5: 1$ \\
\hline Compression ratio & Water cooling \\
\hline Method of Cooling & Eddy current dynamometer \\
\hline Method of Loading &
\end{tabular}

The engine was provided with a crank angle sensor and thermocouples to measure the temperatures of water, air, and exhaust gases. The emission concentrations were recorded with the help of AVL-444 fivegas analyzer and smoke intensity was metered using AVL smoke meter, and the combustion criteria were gauged by the pressure sensing element, Top Dead Centre encoder and data acquisition chord with the aid of a computer.

\section{Experimental Procedure}

After the engine was stabilized at rated speed $(1500 \mathrm{rpm})$, it was allowed to run with pure diesel. The engine was loaded in steps from $0-100 \%$. At each load, the measurements of performance, emission and combustion parameters such as fuel consumption, exhaust gas temperature, hydrocarbon, carbon dioxide, carbon monoxide, oxides of nitrogen, smoke opacity, cylinder pressure, heat release rate and ignition delay were recorded. The same procedure is followed for the test fuels AHME10D90, AHME20D80 and AHME30D70, thereafter the experimental data were analyzed and discussed.

\section{Performance Characteristics}

\section{RESULTS AND DISCUSSION}

Figure-2 communicates the disparity of BSFC (Brake Specific Fuel Consumption) with BP (Brake Power) for all the test fuels. As per the graph, it was found that the BSFC was reduced with an increase in $\mathrm{BP}$, this is because of the requirement of fuel to run the engine is less than that of an increase in brake power as the comparatively small amount of heat is lost at higher loads. The experimental data was revealed that at full load condition the BSFC of AHME30D70 was minimized by $3.46 \%$ when compared to fossil diesel.

Figure-3 exhibits the relation between BTE (Brake Thermal Efficiency) and BP for pure diesel and various blends of AHME. In general, BTE increases with an increase in BP due to better mixing of fuel with air and cut in heat loss at higher engine loads. At full load condition, the BTE of AHME30D70 was increased by $6.39 \%$ as in comparison with conventional diesel, this is because of the reason that the biodiesel possesses more oxygen which causes complete combustion.

\section{Emission Characteristics}

Figure-4 represents the communication between EGT (Exhaust Gas Temperature) and BP of all the fuels which are under test. The temperature of flue gas increases with an increase in B.P. The test result was confirmed that the temperature of exhaust flue gas of AHME samples is low than that of fossil fuel since there might be maximum utilization of heat energy to produce mechanical work which results in less rejection of heat to the environment. At maximum brake power, the EGT of AHME30D70 was effectively come down by $13.2 \%$ compared to fossil diesel.

Figure-5 conveys a percentage change in $\mathrm{CO}_{2}$ (Carbon dioxide) emission with a change in $\mathrm{BP}$. The $\mathrm{CO}_{2}$ percentage in flue gases indicates the state of combustion. If the percentage of $\mathrm{CO}_{2}$ increases, then there could be a possibility of complete combustion of the fuel. From the recorded data it was found at the full load that the percentage of $\mathrm{CO}_{2}$ is merely increased by $0.4 \%$ when the engine is running with 
RASĀYAN J. Chem.

Vol. 13 | No. 2 |876 - 886| April - June | 2020

AHME10D70 and is slightly increased by $2.2 \%$ when the engine is running on AHME30D70 as a comparison with diesel.

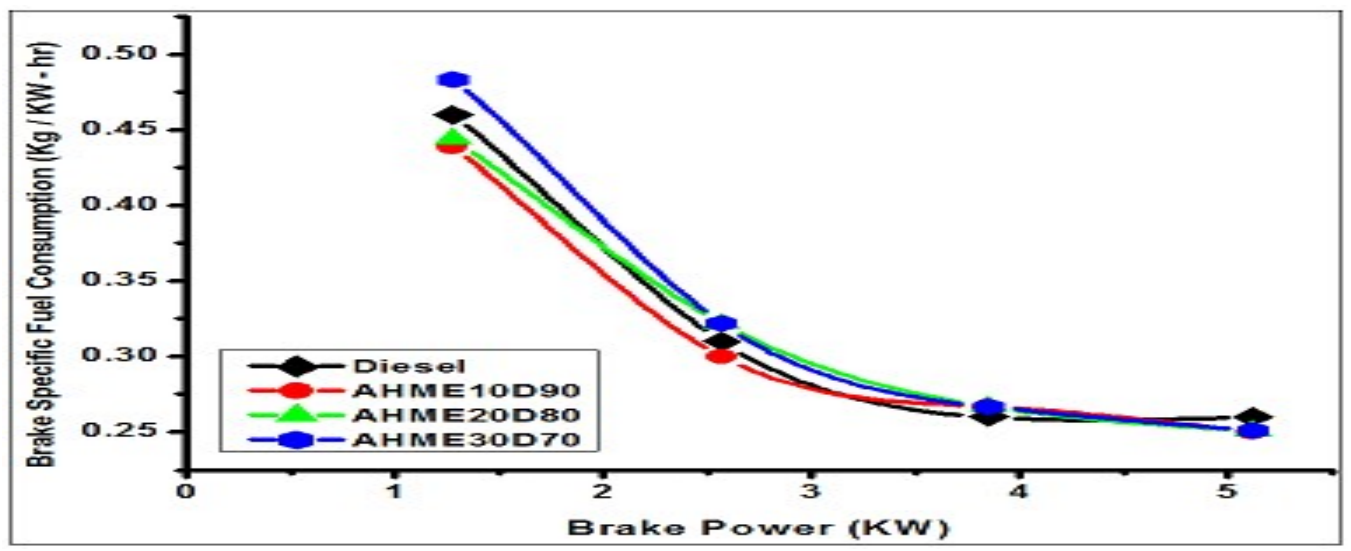

Fig.-2: Variation of BSFC with BP

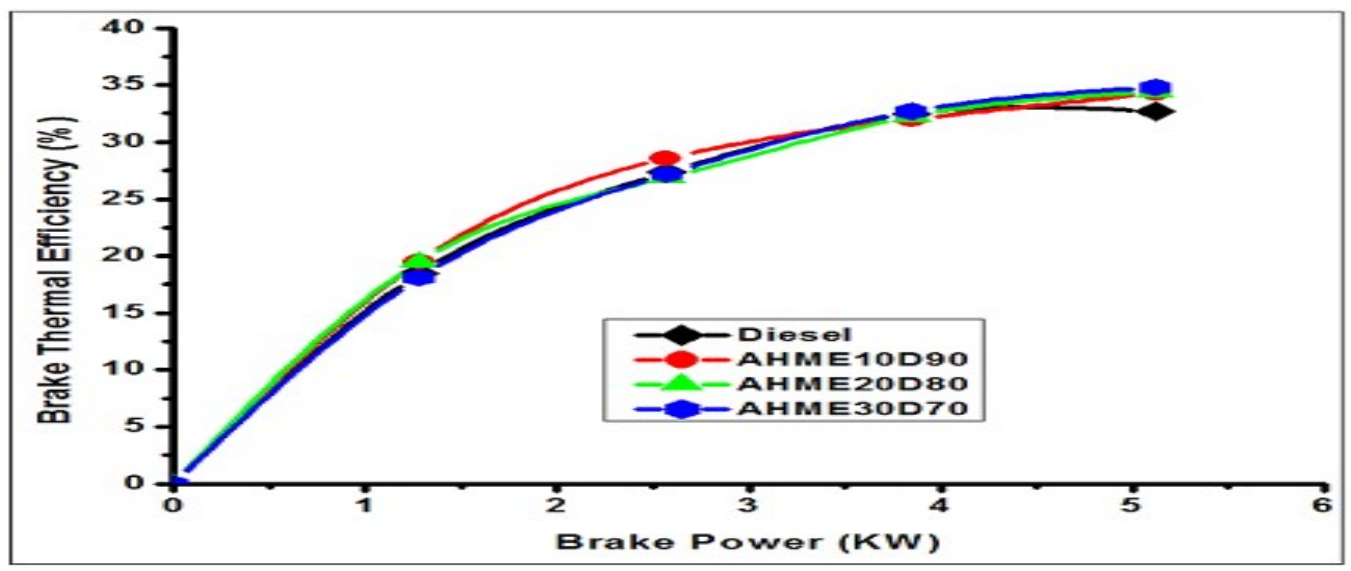

Fig.-3: Variation of BTE with BP

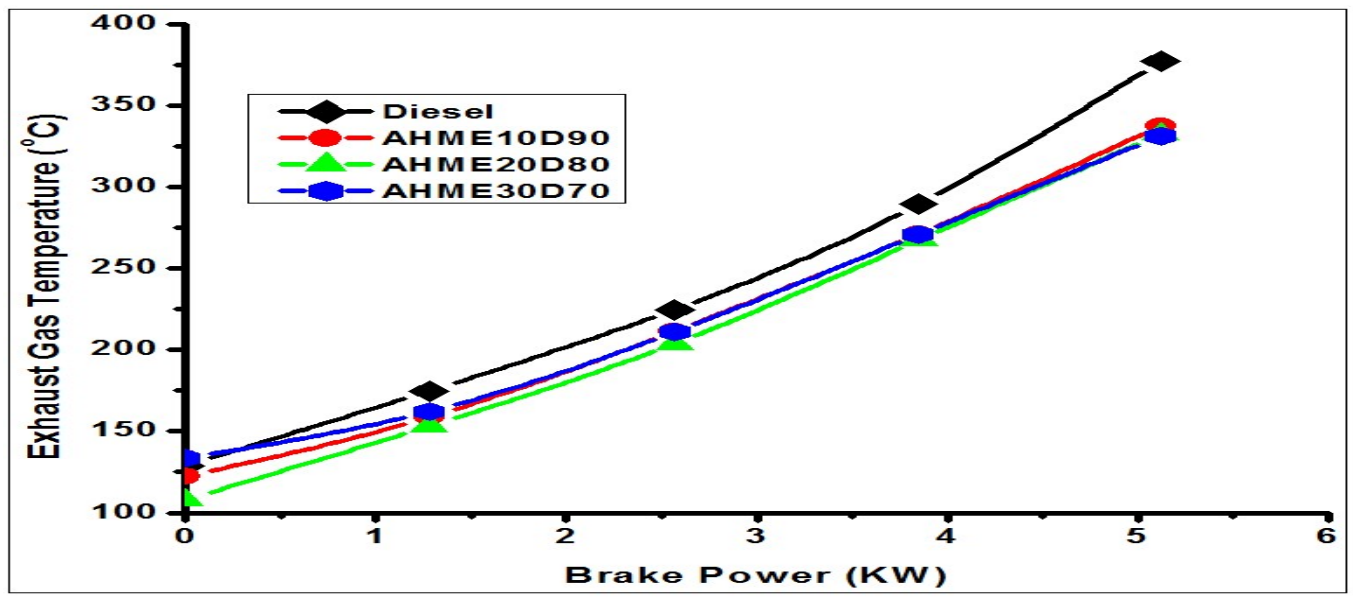

Fig.-4: Variation of EGT with BP

Figure-6 manifests the dissimilitude of CO (Carbon monoxide) emission with BP for all the tested fuels, in actual practice, incomplete combustion causes the formation of $\mathrm{CO}$ due to lack of oxygen in petroleumderived fuels, but the biodiesel is rich in oxygen content. From the experimental observations were conveyed that at maximum load condition the percentage of $\mathrm{CO}$ was greatly decreased by $57.74 \%$ with AHME30D70. 
RASĀYAN J. Chem.

Vol. 13 | No. 2 |876 - 886| April - June | 2020

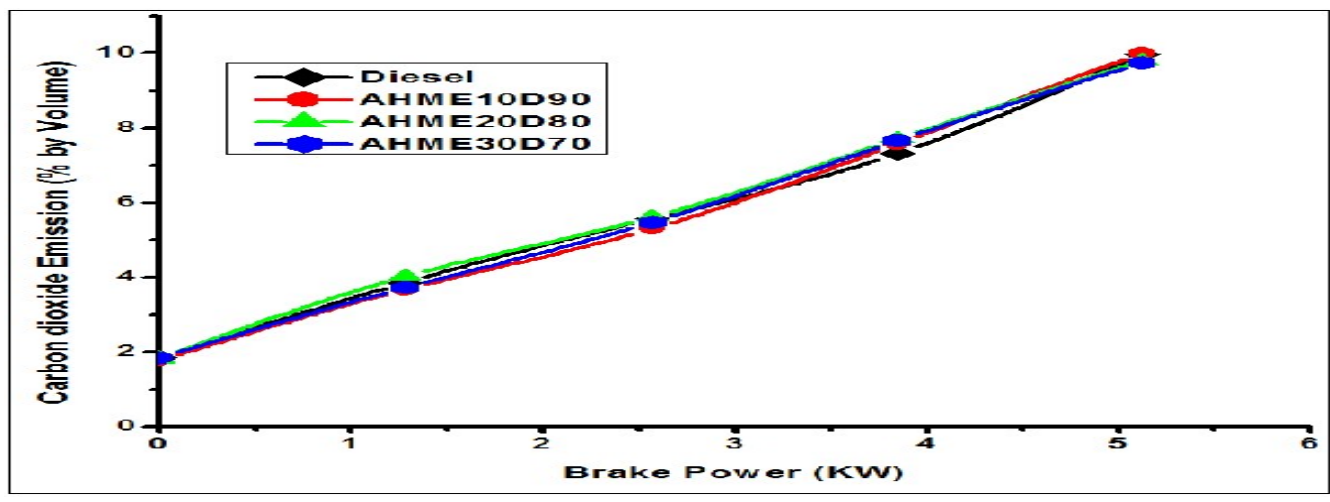

Fig.-5: Variation of $\mathrm{CO}_{2}$ Emission with $\mathrm{BP}$

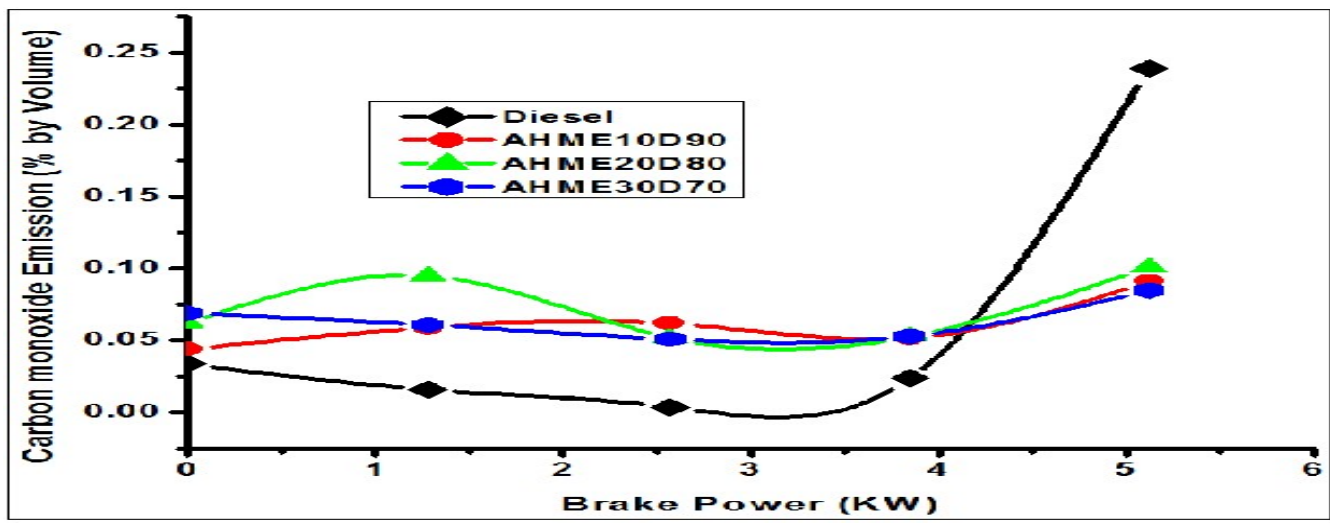

Fig.-6: Variation of CO Emission with BP

Figure-7 depicts the change of $\mathrm{HC}$ (Hydrocarbon) emission concerning the BP for the pure diesel and all the diesel-biodiesel blends. The presence of hydrocarbon in exhaust emission represents the incomplete combustion of the fuel, due to insufficient flame propagation in the combustion chamber. It was cleared from the observations that, hydrocarbon measured in ppm increased with an increase in brake power for all the tested samples. At full load, the hydrocarbon of AHME30D70 is as equal as diesel by $45 \mathrm{ppm}$.

Figure-8 communicates the connection between NOx (oxides of nitrogen) with B.P for pure diesel and various biodiesel blends. The NOx emission is a temperature phenomenon, from the experimental results it was observed that the amount of NOx was increased with B.P increases for all the fuel samples which were tested, there are two reasons basically for this, one is as the load increases the temperature inside the combustion chamber increases and the another is biodiesel is rich in oxygen content. At initial loads, NOx for diesel and biodiesel blends is very much lesser than pure diesel, but at higher loads, NOx was increased than that of pure diesel by $13.19 \%$.

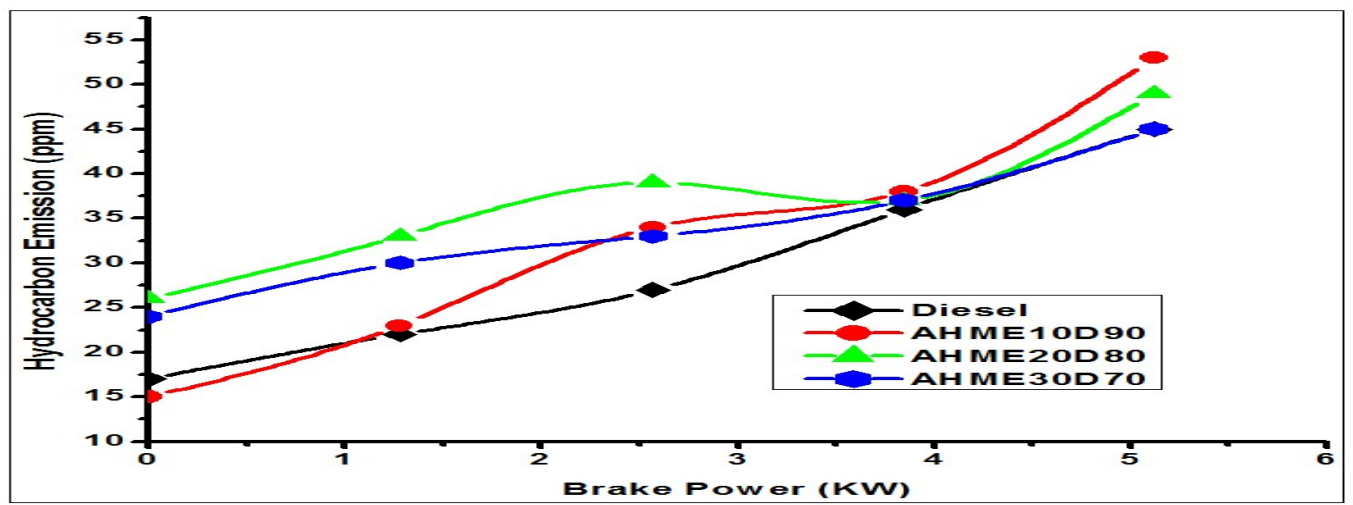

Fig.-7: Variation of HC Emission with BP 
RASĀYAN J. Chem.

Vol. 13 | No. 2 |876 - 886| April - June | 2020

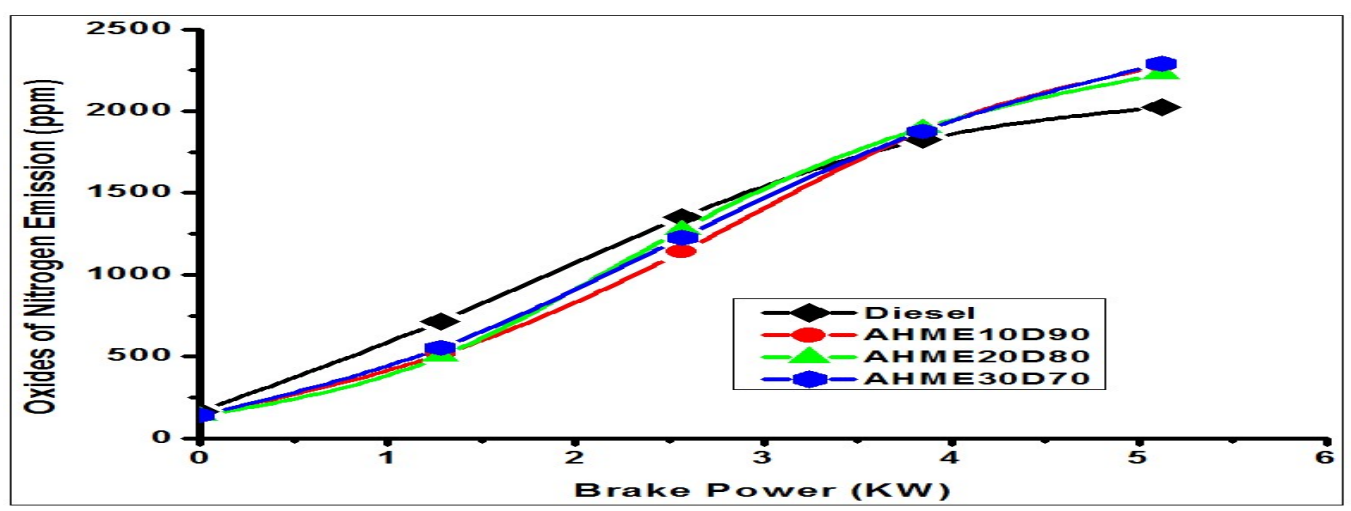

Fig.-8: Variation of $\mathrm{NO}_{\mathrm{X}}$ Emission with BP

Figure-9 displays the disparity between smoke opacity in percentage and BP for all test samples. As per the results, the smoke opacity increases with an increase in the load, but the increment is less for blends AHME20D 80 and AHME30D70 by $15.21 \%$ and $5.5 \%$ respectively as a comparison with conventional diesel.

\section{Combustion Characteristics}

Figure-10 represents the relation between cylinder peak pressure and B.P for all tested fuel samples, from the graph it was noticed that the peak pressure was increased steadily with an increase in brake power. The variation in-cylinder peak pressure purely relies upon the quantity of fuel oil involved in the uncontrolled combustion phase, being affected by the duration of the delay period. As the delay period increases the amount of fuel accumulation increases in the premixed combustion phase. It can be justified through the results, that at full load the maximum cylinder peak pressure of AHME30D70 is $73.20 \mathrm{bar}$ and that of diesel is 71.77 bar, hence it was increased by $2 \%$.

Figure-11 shows the variation of MHRR (Maximum heat release rate) concerning B.P for pure diesel and all biodiesel blends. From the test results, it has been found that for all the blends the MHRR was gradually increased with an increase in brake power, but at full load, it was dramatically dropped for diesel as well as biodiesel blends. This is due to a reduction in the premixed combustion phase and may be of an increase in ignition delay. At full load, the MHRR for diesel is $43.07 \mathrm{~J} /{ }^{0} \mathrm{CA}$ and for AHME30D70 is $38.45 \mathrm{~J} /{ }^{\circ} \mathrm{CA}$.

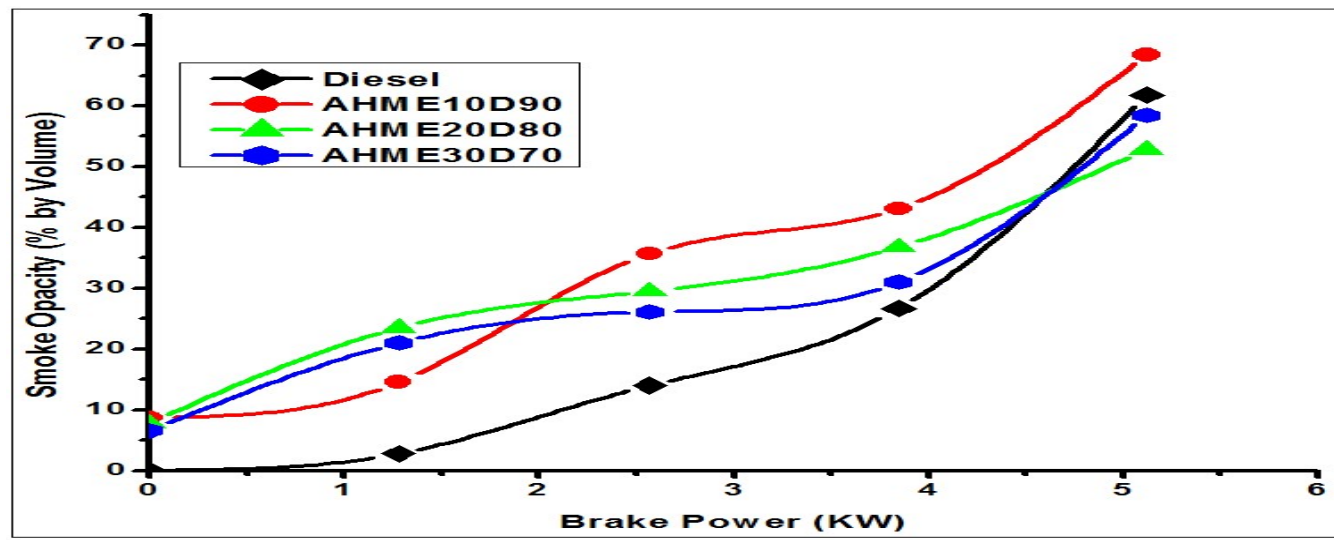

Fig.-9: Variation of Smoke Opacity with BP

Figure-12 illustrated the variation of ignition delay period along with B.P for pure diesel and biodiesel blends. The ignition delay can be estimated in terms of the crank angle difference between the start of combustion and the start of injection. As the figure represents, ignition delay decreases with an increase in brake power. The diminution in ignition delay for biodiesel is quicker than that of diesel as the faster combustion of biodiesel. At full load, the ignition delay for diesel and biodiesel blend AHME30D70 is $11^{\circ} \mathrm{CA}$ and $9^{\circ} \mathrm{CA}$ respectively. 
RASĀYAN J. Chem.

Vol. 13 | No. 2 |876 - 886| April - June | 2020

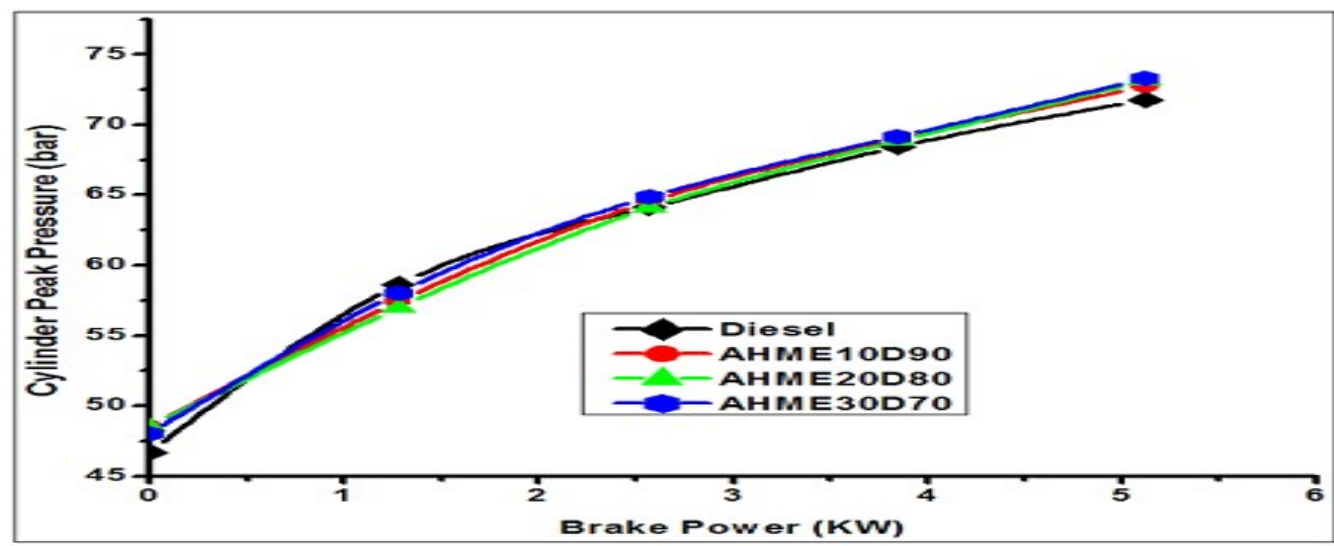

Fig.-10: Variation of Cylinder Peak Pressure with BP

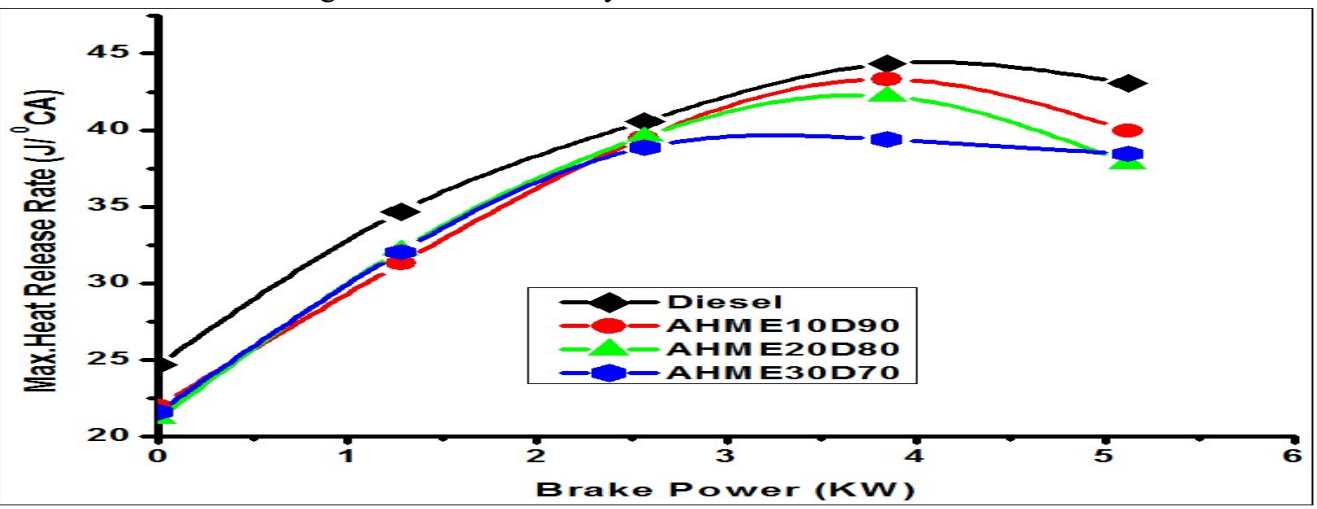

Fig.-11: Variation of Maximum Heat Release Rate with BP

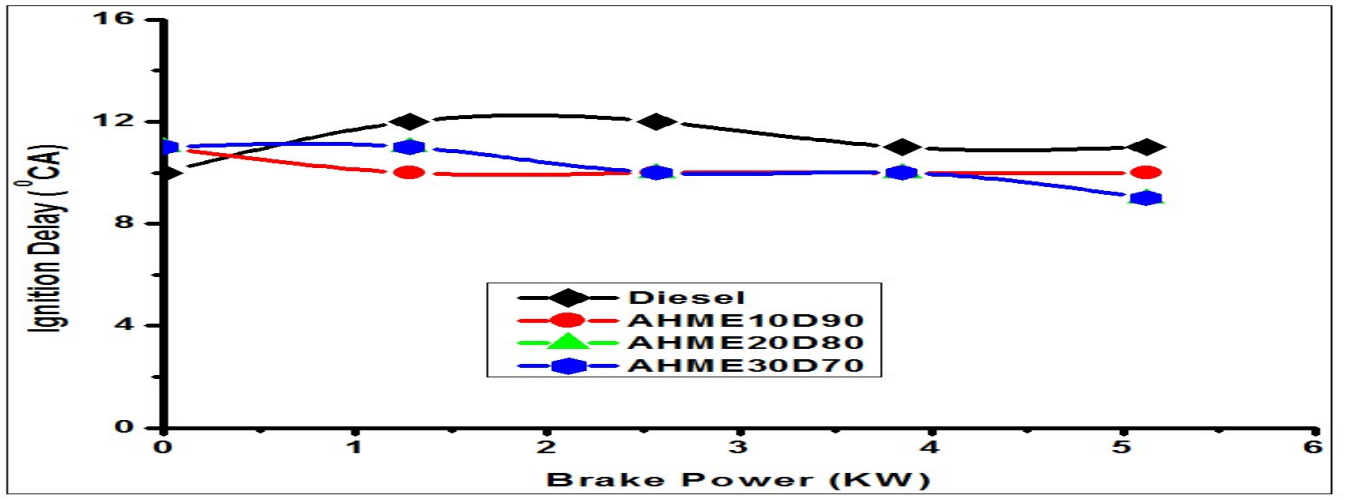

Fig.-12: Variation of Ignition Delay with BP

\section{CONCLUSION}

To make lessen the outcome concentrations and to improve performance and combustion features of a compression ignition engine, a single-cylinder four-stroke diesel engine was driven successfully when charged with pure diesel and Artocarpus heterophyllus methyl ester blends at a constant speed with varying load and lastly, the following conclusions are drawn in comparison with conventional pure diesel at $100 \%$ load,

1. BSFC was reduced by $3.46 \%$ with AHME30D 70 ,

2. BTE was improved by $3.69 \%$ with AHME30D 70 ,

3. EGT was lower and it was reduced by $13.20 \%$ with AHME30D70,

4. The percentage of $\mathrm{CO}$ was quite low, and it was greatly reduced by $57.74 \%$ when the engine is powered by AHME30D70,

5. $\mathrm{CO}_{2}$ percentage was slightly incremented by $2.2 \%$ when the engine is running on AHME30D 70 , 
6. No significant difference was occurred in the percentage of $\mathrm{HC}$ and is equal to $45 \mathrm{ppm}$ as that of diesel,

7. For all diesel and AHME blends the NOx emission was more than that of pure diesel, but for AHME30D70 it is lesser by $13.19 \%$ off other blends,

8. Off other blends, AHME30D70 has registered less percentage of smoke opacity, but at $100 \%$ load it is slightly increased by $5.5 \%$ than conventional fuel,

9. The peak pressure of AHME30D70 is 73.20 bar and is increased by $2 \%$ fossil diesel,

10. Off other biodiesel samples, AHME30D70 showed maximum HRR of $38.45 \mathrm{~J} /{ }^{0} \mathrm{CA}$ but it was brought down to pure diesel by $10.73 \%$.

From the above conclusions, it was resolved that Artocarpus heterophyllus methyl ester at $30 \%$ blend with diesel exhibited better performance and emission characteristics without any engine modification, hence Artocarpus heterophyllus seed may be considered as one of the possible alternate feedstock in the future for producing biodiesel which can be used in compression ignition engines to improve engine emissions and performance.

\section{REFERENCES}

1. Demibras, Biodiesel, 185, 194(2008), DOI:10.1007/978-1-84628-995-8_9

2. Sheehan, J. Cambreco, J. Graboski, M., and Shapouri H, US Department of Agriculture and Energy Report, 1, 35(1998), DOI:10.2172/771560

3. Nambaya Charyulu Tatikonda, and P. Naveenchandran, International Journal of Management, IT \& Engineering, 218, 43(2018)

4. Hwai Chyuan Ong, A.S. Silitonga, T.M.I. Mahila, H.H. Masjuki, and W.T. Chong, Energy Procedia, 61, 436 (2014), DOI:10.1016/j.egypro.2014.11.1143

5. A.E. Atabani, and Aldara da Silva Cesar, Renewable and Sustainable Energy Reviews, 37, 644(2014), DOI: 10.1016/j.rser.2014.05.037

6. Nambaya Charyulu Tatikonda, and P. Naveenchandran, International Journal of Mechanical and Production Engineering, Research and Development, 9(4), 447(2019), DOI: 10.24247/ijmperdaug201944

7. R. Satish Kumar, K. Suresh Kumar, and R. Velraj, Fuel, 140, 90(2015), DOI: $10.1016 /$ j.fuel.2014.09.103

8. S. Sendilvelan, and K. Bhaskar, Rasayan Journal of Chemistry, 10(3), 1043(2017) DOI: 10.7324/RJC.2017.1031703

9. Nambaya Charyulu Tatikonda, and P. Naveenchandran, International Journal of Engineering and Advanced Technology, 8(6), 3285(2019), DOI:10.35940/ijeat.F9500.088619

10. V.K. Shahir, C.P. Jawahar, and P.R. Suresh, Renewable and Sustainable Energy Reviews, 45, 686(2015), DOI:10.1016/j.rser.2015.02.042

11. M. Mofijur, M.G. Rasul, J. Hyde, and M.M.K. Bhuyia, Energy Procedia, 75, 886(2015), DOI:10.1016/j.egypro.2015.07.211

12. Nambaya Charyulu Tatikonda, and P. Naveenchandran, International Journal of Innovative Technology and Exploring Engineering, 8(11), 834(2019), DOI:10.35940/ijitee.K1499.0881119

13. M. Saravanakumar, M. Prabhakar, Sangeetha Krishnamoorthi, and S. Sendilvelan, Rasayan Journal of Chemistry, 11(1), 372(2018), DOI:10.7324/RJC.2018.1112024

14. A.K. Azad, M.G. Rasul, M.M.K. Khan, Subhash C. Sharma, and Rubayat Islam, Procedia Engineering, 105, 601(2015), DOI: 10.1016/j.proeng.2015.05.037

15. R.M. Alagu, and E. Ganapathy Sundaram, Journal of the Energy Institute, 91(1), 100(2018), DOI: 10.1016/j.joei.2016.10.003

16. J. Kakati, T.K. Gogoi, and K. Pakshirajan, Energy Conversion and Management, 135, 281(2017), DOI: 10.1016/j.enconman.2016.12.087

17. L. Tarabet, K. Loubar, M.S. Lounici, K. Khiari, T. Belmrabet, and M. Tazerout, Fuel, 133, 129(2014), DOI:10.1016/j.fuel.2014.05.008

18. Mohamed F. AI Dawody, and S.K. Bhatti, Energy Procedia, 52, 421(2104), DOI: 10.1016/j.egypro.2014.07.094 
RASĀYAN J. Chem.

Vol. 13 | No. 2 |876 - 886| April - June | 2020

19. Md. Nurnn Nabi, Md. Mostafizur Rahman, Muhammad Aminul Islam, Farhad M. Hossain, Peter Brooks, William N. Rowlands, John Tulloch, Zoran D Ristovski, and Richard J. Brown, Energy Conversion and management, 96, 588(2015), DOI:10.1016/j.enconman.2015.02.085

20. Issac Joshua Ramesh Lalvani, Parthasarathy M, Dinesh B, and Annamalai K, Journal of Mechanical Science and Technology, 29(10), 4519(2015), DOI:10.1007/s12206-015-0951-y

21. S. Nallusamy, S. Sendilvelan, K. Bhaskar, and N. Manikanda Prabu, Rasayan Journal of Chemistry, 10(3), 873(2017), DOI:10.7324/RJC.2017.1031787

22. S. M. Ameer Uddin, A. K. Azad, M. M. Alam, and J. U. Ahamed, Procedia Engineering, 105, 698(2015), DOI:10.1016/j.proeng.2015.05.059

23. Omar I. Awad, Rizalmanmmat, Obed M. Ali, I. M. Yusri, A.A. Abdullah, A.F. Yusop, and M.M. Noor, Journal of the Energy Institute, 1, 15(2016), DOI:10.1016/j.joei.2016.04.004

24. K. Khiari, S. Awad, K. Loubar, L. Tarabet, R. Mahmoud, and M. Tazerout, Energy Conversion and Management, 108, 392(2016), DOI:10.1016/j.enconman.2015.11.021

25. Harveer Singh Pali, and Naveen Kumar, Combustion, Biofuels, 7(5), 447(2016), DOI: $10.1080 / 17597269.2016 .1153363$

26. Ashok Kumar Yadav, Mohd. Emran Khan, and Amit Pal, Korean Journal of Chemistry, 34(2), 340(2017), DOI:10.1007/s11814-016-0270-8

27. Praveen A. Harari, Integrated Research Advances, 4(1), 18(2017)

28. B. Dhinesh, and M. Annamalai, Journal of Cleaner Production, (196), 74(2018), DOI:10.1016/j.jclepro.2018.06.002

29. R. Sundara Raman, G. Sankara Narayanan, N. Manoharan, and S. Sendilvelan, Rasayan Journal of Chemistry, 10(3), 944(2017), DOI:10.7324/RJC.2017.1031664

30. M. Rengasamy, R. Vinoth Raj, and N. Vedagiriswaran, Elixir Renewable Energy, (102), 44269(2017)

31. Nagarajan Jeyakumar, Bose Narayanasamy, and B. Venkatraman, International Journal of Ambient Energy, 1(2019), DOI: 10.1080/01430750.2019.1621202

[RJC-5560/2019] 